\title{
Transition to school process of children with disadvantages: A literature review*
}

\author{
Gamze Kaplan', Sima Mart ${ }^{2}$, ibrahim Halil Diken ${ }^{3}$
}

\begin{abstract}
Transition to school can be described as an opportunity for children to experience a new social and educational environment. However, it also includes a loss of security area and fear of the journey into the unknown and it can be more difficult for children with disadvantages and their families. It is necessary to address the recent studies conducted on this period, in order to present different perspectives and to determine the tendency of the studies carried out on the transition to primary school in the current literature. In this way, it is possible to look at the transition to school for children with disadvantages from a broad perspective. The aim of this study is to review the research that addresses the transition process of children with disadvantages to primary school. Following the inclusion and exclusion processes carried out in this context, 15 studies related to the subject were examined and the studies were analyzed descriptively. According to the findings, it is seen that the studies mostly focus on revealing the existing situation. The findings of the studies examined in this context are interpreted under the themes of (a) factors affecting the transition of children, (b) problems experienced in the transition, (c) collaboration in the transition, and (d) advices for the process. Findings reveal the importance of each individual in a community at the same risk having their own characteristics, and of considering individual differences while addressing cultural differences. It is thought that new research is needed to improve the transition in terms of inclusivity.
\end{abstract}

\section{Article History}

Received: 24 May 2021

Accepted: 30 November 2021

Keywords

Transition, Primary school;

Additional support;

Children with disadvantage;

Literature review

\section{Introduction}

Transition is a process of movement that covers a significant part of life and continues from infancy to adulthood (Rous et al., 2007). The individual is faced with many transition points that take her/him one step further from the existing position. These transition points include the transition of the individual from the starting of the life as the hospital to home until the end of the life. In school environments, transitions can occur in a variety of ways, such as entering school for the first time, transitioning from one school level to another, and transition from one school to another (Ladd \& Price, 1987; LoCasale-Crouch et al., 2008). Additionally, this transition could also be from home to the primary school depending on the access to education within the context (United Nations Educational, Scientific and Cultural Organization [UNESCO], 2010).

Transition to school can be described as an opportunity for children to experience a new social and educational environment. However, this transition also includes a loss of secure area and fear of the journey into the unknown (Visković, 2018). In the first years of school age, there are alterations in philosophical views that make a difference between preschool and primary school. This situation means that the transition to primary school symbolizes a critical period within the child life (Corsaro \& Molarini, 2000).

In preschool philosophy, childhood is handled with a more holistic approach based on care and developmental progression with the priority of the child's wellbeing and enjoyment. However, when

\footnotetext{
*This study was presented orally in 5th National Interdisciplinary Early Childhood Intervention Congress (UDEMKO, 2020) held on 27-29 June 2020.

${ }^{1}$ University of Manchester, Faculty of Biology, Medicine and Health, Psychology, Manchester, UK, e-mail: gamzekaplan175@gmail.com, ORCID: https://orcid.org/0000-0003$\underline{4613-1359}$

${ }^{2}$ Anadolu University, Research Institute for Individuals with Disabilities, Eskişehir, Turkey, e-mail: skirkgoz@anadolu.edu.tr, ORCID: https://orcid.org/0000-0003-0290-1024

${ }^{3}$ Anadolu University, Research Institute for Individuals with Disabilities, Eskişehir, Turkey, e-mail: ihdiken@anadolu.edu.tr ORCID: https://orcid.org/0000-0002-5761-2900
} 
children start primary school they come across with an intense contrast within the traditional education system (Woodhead \& Moss, 2007). In several countries such as Sweden, Scotland and New Zeland, there is a tendency to change the traditional system with a more pedagogical approach based on child's wellbeing and creativity instead of competition (Moss \& Bennett, 2006). In this respect, in addition to good examples, suggestions in academic studies continue and a "pedagogical meeting place" is emphasized This concept means reflecting and constructing the pedagogical practices together with the democratic and fair participation of the child in the process (Bennett, 2013). Extensively, it is common to find out the approach that underestimated the importance of early childhood education and care and the perception of it is like a preparation for formal schooling (Moss \& Bennett, 2006). Play-based methods, which are fundamental in preschool education, turn into large group teaching for specific content areas in primary school (Dahlberg \& Taguchi, 1994; Einarsdóttir et al., 2008). Thus, within the current education system, there is a need to conduct more research focused on the organisations, readiness concept for school, child and community and approach to transition and pedagogy in early childhood and primary school settings.

When children develop a positive attitude towards school during the transition to primary school and have the support they need, such as social support, positive improvements will be achieved in their level of school readiness (Becker \& Luthar, 2002). School readiness refers to a set of skills or preparation associated with the harmony of child and school systems and it is included the child's and school's readiness for the child (Ahtola et al., 2011). Also, readiness is a fundamental responsibility of the community to reach the rights and equal opportunities within the system (Woodhead \& Moss, 2007). Children who are ready for school will show adaptive behaviours that will affect their future academic and social skills instead of reactions such as anxiety, avoidance or negative attitudes towards school (Graue, 2006; Ladd \& Price, 1987).

The transition from preschool to primary school is a fundamental process for all families and children, and it can be more difficult for children with disadvantages and their families (Ames, 2012; Pianta et al., 1999). Although disadvantage is quite a relative concept, many factors affect a child's disadvantage. UNESCO (2010) has described individuals with disadvantage under four categories. These are (a) individuals with a low socioeconomic level associated with poverty, (b) individuals with group differences such as ethnicity, religion, and language, (c) those living in rural areas or immigrants, and (d) individuals with special educational needs. This classification provides a framework consistent with the "precarious living conditions" offered by Walper and Riedel (Gambaro et al., 2014) and, in a broader sense, refers to having additional support needs in terms of social and educational aspects. For example, research shows that there is an intersection with poverty in many types of disability and suggests that additional resources and services should be used to address systemic inequalities (Riddell \& Weedon, 2016). While the lack of government support and weak regulatory systems create problems for all children, these results are more common for children who need additional support (Gambaro et al., 2014).

When the system for a smooth transition is considered, it is of great significance for children who need additional support to know how this process takes place and to review the work carried out in this regard. Yet there are limited studies that aim to review the research conducted on this period (Petriwskyj et al., 2005). In the study conducted by Petriwskyj et al. (2005), the studies on transition to school between 1990 and 2004 were reviewed. The main purpose of the study was to investigate and interpret the trends in how the concept of transition was created in parallel with the need for publication time. The authors only included studies carried out in three western regions due to the variations of school transition patterns and mostly focused on the construction of transition to school. This study, on the other hand, separated significantly from the previous study with its features such as not having any regional boundaries detailed explanation of the systematic screening process, covering descriptive information that will enable readers to look at the transition to school for children with disadvantages from a broad perspective, and providing the information from up-to-date studies. Therefore, it is necessary to address the recent studies conducted on this period, in order to present different perspectives and to determine the tendency of the studies carried out on the transition to primary school in the current literature. Due to the wide variety of the participant population, studies need to be reviewed more holistically in terms of the interventions and the 
processes taking place during the transition period. This review will enable broader decision-making on best practice procedures and regulations for different students and contexts. For this reason, this study aims to review the literature on the transition of children with disadvantages to primary school.

\section{Method}

In this section, information about the methodology of the research, electronic screening and coding of the data and reliability are included.

\section{Methodology of the Research}

This research is a review of previous studies conducted on the transition to primary school, which is one of the important steps in the transition of children.

\section{Electronic Screening}

This review study includes the studies that were published in an international peer-reviewed journal in English or Turkish after 2005 and focused on the transition of children with a disadvantage to primary school. To identify the articles published in English, peer-reviewed academic journals between 2005 and 2020, we searched 11 electronic bibliographic databases: Academic Search Ultimate, Central \& Eastern European Academic Source, Directory of Open Access Journals, ERIC, JSTOR Journals, Medline, ScienceDirect, Scopus, Springer Nature Journals, Teacher Reference Center, and The Belt and Road Initiative Reference Source.

Within the scope of this study, the terms "transition to school" OR "transition to elementary" OR "transition to inclusion" OR "transition to primary" were screened in Central Search and Article Linker service within the university library system. The "Also search within the full text of articles" option was used as the expander. In order to limit the studies, the conditions of "being in the library collection", "being published in a peer-reviewed academic journal" and "being in English" were applied. After the screening according to the determined criteria, 1421 studies were accessed.

In the next stage, the screen was limited to the subjects of "education", "transition", "early childhood education", "children", "primary education", "transitional programs", "elementary education", "academic achievement", "schools", “longitudinal method", "school children", "kindergarten", "students", "student adjustment", "formal education", "school transition", "elementary schools", "child development", "elementary school students", "school readiness", "special education", "transition to school", "preschool children", "preschool education" and "transitional programs (education)". After applying this limitation, 630 studies were accessed. The titles and abstracts of 630 studies were reviewed by two authors independently and simultaneously in line with the criteria determined, and duplicates were excluded. After these procedures, the number of studies decreased to 93.

Selecting criteria are (a) being in the library collection, (b) being published in a peer-reviewed academic journal, (c) in English and (d), at least one participant is a disadvantage. The concept of transition to school is handled in different ways in research (Atkinson et al., 2021; Helm et al., 2019), but in this study, as mentioned in the introduction part, it is considered as Grade 1 since it symbolizes the transition to a formal approach in the current education system. Therefore, pre-school education, or reception class is excluded. In the dimension of disadvantage, since the concept has a broad meaning, no relevant phrase is included in the keywords. After the screening, the topics selected among the available topic options were evaluated within the framework of UNESCO's definition of disadvantage and kept as wide as possible.

It was decided to include only studies after 2005 in order to reach up-to-date data and contribute the literature although the purpose and content of this study are different from Petriwskyj et al. (2005). In this stage, informative articles, articles in which the term "transition to school" refers to preschool education, kindergarten or reception class and articles targeting children who have not any disadvantage that has mentioned in the classification of the UNESCO were left out. The full texts of 93 studies were looked into according to the criteria (a) type of disadvantage, (b) transition to school, and (c) being after 2005, and after 
this review, the number was reduced to 13 . The bibliographies of the included studies were manually screened and two new studies (McIntyre et al., 2006; Walker et al., 2012) were included. After all the eliminations, 15 articles were reviewed within the scope of this research. The steps followed during the screening process are presented in Figure 1.

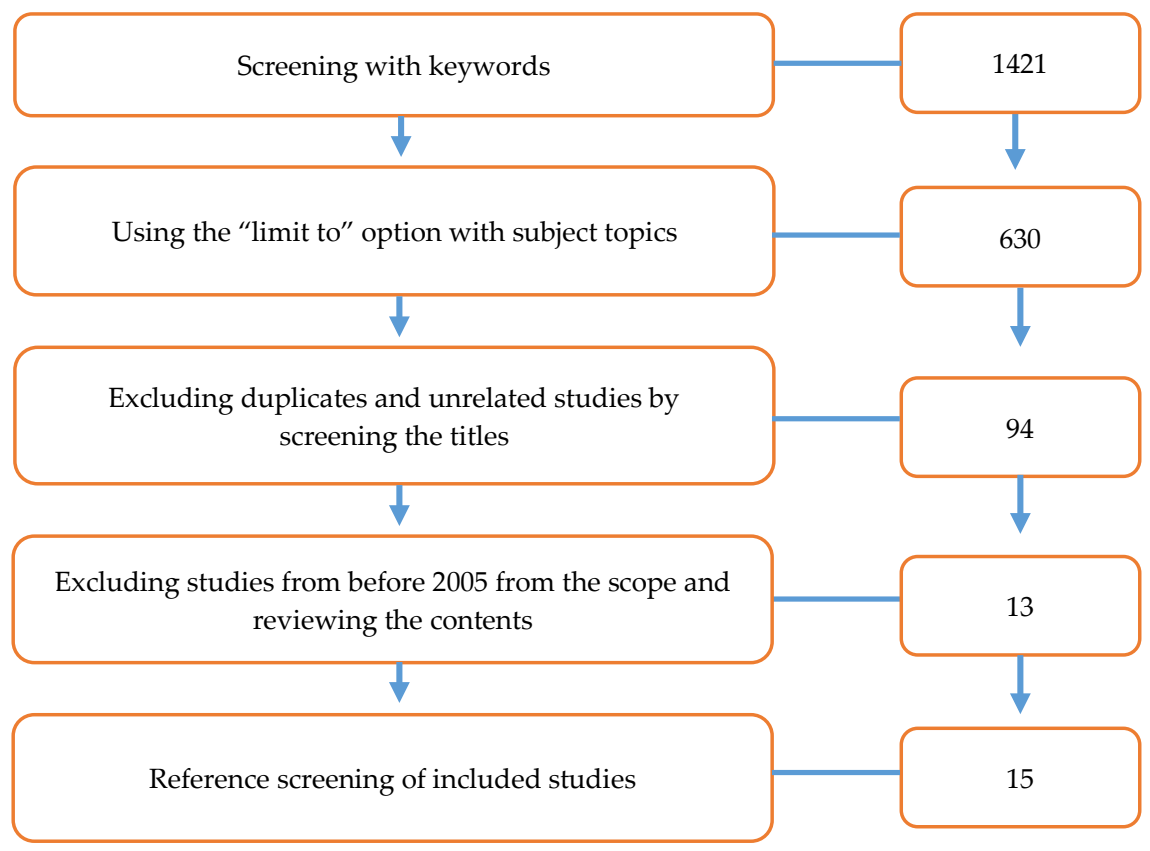

Figure 1. Screening steps

\section{Coding}

The variables of 15 studies, which were included in the screening process and thought to be related to the subject, were coded. In order to code the variables, a descriptive analysis table was created and the basic data were presented on this table. These variables were examined under the following headings: (a) year, (b) country, (c) aim of the research, (d) participants, (d) type of disadvantage, (e) research method, (f) data collection techniques, (g) findings, and (h) reliability/trustworthiness. Each study was examined from the first item of the descriptive analysis table to the last item. In addition, the journals in which the researches were published were presented as a list and presented to the reader's information.

\section{Reliability}

The electronic screening process of the study was carried out by the first author, and all other stages were carried out independently and simultaneously by the first and second authors. 630 articles were evaluated simultaneously and independently by two researchers during the evaluation phase according to the pre-selection and inclusion criteria of the research. Afterwards, a meeting was held and disagreements were resolved and a consensus was reached. At this stage, it was undecided about the inclusion of food allergies. However, the concept of special educational needs has been included because it requires additional regulation and support rather than the context of disability. In the manual scanning phase, the bibliographies of the articles were reviewed.

In the coding phase of the variables, the researchers created a descriptive analysis table and adopted a common path by holding a meeting on how to fill the table. The researchers read and coded the studies independently of each other as in the other stages. After the coding, the differences of opinion were reviewed and a meeting was held and a consensus was reached on these points. In this step, only corrections were made on issues such as word corrections and clarity.

The first and second authors who took an active role in the review process, proceed with their education as doctoral students in the field of special education and took part in the conduct of the various review, systematic review and meta-analysis studies. In addition, the third author, who works as a 
professor in the field of special education, provided supervision during the planning and implementation of the research steps.

\section{Findings and Interpretation}

In this section, the main findings and the interpretation of the studies with current literature is included. A summary of the descriptive data including year, country, aim type of disadvantage, methodology, data collection techniques, findings and reliability/trustworthiness is presented in Table 1. Table 2 provides the information of the journals in which the studies were published.

Children with disadvantages may experience additional difficulties in the transition process (Ames, 2012; Sanagavarapu, 2010) and there are different individual decisions and practices depending on the needs of each child. For this reason, the process of transition to school cannot always be interpreted clearly in the studies examined. Looking at how to transition to school is defined in the studies, and it was explained as (a) a long-term process covering the previous and subsequent years in the institution (BellBooth et al., 2014; Petriwskyj, 2013; Sanagavarapu, 2010; Sanagavarapu et al., 2016; Schischka et al., 2012; Walker et al., 2012), (b) a shorter-term process that requires a number of preparations (Carmody et al., 2015; Chang et al., 2012; Fontil \& Petrakos, 2015; Rogers, 2018; Yıldırım-Haciibrahimoğlu \& Kargın, 2017), and (c) critical moments (Ames, 2012). In the other review study (Petriwskyj et al., 2005), it is seen that there are different definitions such as a school starting process reduced to teacher practice, ensuring continuity from home to school and a multi-layered process. This situation reveals the complexity of the transition process and its unique counterpart.

In terms of geography, eight of the studies were carried out in Australia, three in the USA, one in Canada, one in New Zealand, one in Peru and one in Turkey. Considering that there is considerable differences in legal regulations in these regions, but the current trend in for Australia to have the highest level of research may be related to the existing trend in transition studies (Dockett et al., 2014) and the differences in implementation between regions, despite the existence of legal regulations in Australia (Einarsdóttir et al., 2008). For example, in Queensland, many children with disadvantages attend primary school a few days a week and an intervention class on other days. In the second year, the transition is completed and they start school full-time (Walker et al., 2012). But not all states in Australia have such a process. Moreover, it is possible to see a wide variety of practices in different countries of the world in connection with education policies. For this reason, it is thought that this review will gain a global perspective (Walker et al., 2012). In addition, the fact that studies have been conducted one in each country that Turkey (Yıldırım-Haciibrahimoğlu \& Kargın, 2017), Peru (Ames, 2012), Canada (Fontil and Petrakos, 2015) and New Zealand (Schishka et al., 2012) is a promising situation for the new and developing literature for transition studies.

Aims of the research were to investigate child and their relatives' opinions, experiences and feelings about transition and starting school $(n=6)$, to identify needs of mothers in the transition $(n=1)$, to identify difficulties in the process $(n=2)$, to design and evaluate an effective transition $(n=2)$, to identify key factors in transition $(n=2)$ and to examine the predictive level of child-related variables $(n=2)$ across 15 studies. It is seen that the majority of the studies focus on exploring the current situation, and effectiveness studies are in the minority. Exploratory research is primarily preferred in cases where (a) experimental research on the area is limited, (b) research describing the area is limited, or (c) current developments in the area require new research (Stebbins, 2001). Although the subject of school readiness has existed for many years, the transition point of view that emerged after the modern changes in perspective is considered as a subject area that changes and updates day by day, and it is thought that exploratory studies will contribute significantly to the literature and light up the way for comprehensive research (Babbie, 2004). 
Transition to school process of children with disadvantages...

Table 1. Studies examining transition to school of children with disadvantage

\begin{tabular}{|c|c|c|c|c|c|c|c|}
\hline $\begin{array}{c}\text { Author/Year/ } \\
\text { Country }\end{array}$ & Aim & Participant/s & $\begin{array}{c}\text { Type of } \\
\text { disadvantage }\end{array}$ & Method & $\begin{array}{c}\text { Data collection } \\
\text { techniques/ } \\
\text { Tools }\end{array}$ & Findings & $\begin{array}{l}\text { Reliability/ } \\
\text { Trustworthin } \\
\text { ess }\end{array}$ \\
\hline $\begin{array}{l}\text { Sanagavarapu, } \\
\text { 2018/ Australia }\end{array}$ & $\begin{array}{l}\text { (1) Identify the } \\
\text { experience, anxiety, and } \\
\text { support needs of mothers } \\
\text { of children with food } \\
\text { allergies in the transition } \\
\text { to school, } \\
\text { (2) Provide advice to } \\
\text { families on how to ensure } \\
\text { a safe and positive start to } \\
\text { school }\end{array}$ & $\begin{array}{l}10 \text { school-age } \\
\text { students with } \\
\text { food allergies } \\
\text { and their } \\
\text { mothers }\end{array}$ & Food allergy & Qualitative & $\begin{array}{l}\text { Interview } \\
\text { Photo Elicitation } \\
\text { Interviews (PEI) }\end{array}$ & $\begin{array}{l}\text { The vast majority of families stated that the transition } \\
\text { did not happen as planned, so it was a stressful and } \\
\text { challenging time. Mothers stated that systematic } \\
\text { follow-up of school nurses with action plans } \\
\text { prepared by schools during the transition facilitated } \\
\text { the period; lack of communication, failures in the } \\
\text { transition plan and family participation made the } \\
\text { transition difficult. }\end{array}$ & $\begin{array}{l}\text { Inter-rater } \\
\text { reliability }\end{array}$ \\
\hline $\begin{array}{l}\text { Rogers, } \\
\text { Australia }\end{array}$ & $\begin{array}{l}\text { Understanding the } \\
\text { perspectives of mothers } \\
\text { and teachers on family } \\
\text { participation during the } \\
\text { transition of children who } \\
\text { experience difficulties in } \\
\text { the time of transitioning } \\
\text { to school }\end{array}$ & $\begin{array}{l}21 \text { mothers } \\
\text { and } 13 \\
\text { primary } \\
\text { school } \\
\text { teachers }\end{array}$ & $\begin{array}{l}\text { Socio-economic } \\
\text { disadvantage }\end{array}$ & Case study & $\begin{array}{l}\text { Observation } \\
\text { Interview } \\
\text { Document analysis } \\
\text { Informal conversation }\end{array}$ & $\begin{array}{l}\text { Mothers mostly participated in their children's } \\
\text { education at home, in the context of homework and } \\
\text { games and they were looking for regular } \\
\text { communication opportunities to share their concerns } \\
\text { and talk about their children. } \\
\text { Mothers who regularly participated in a weekly } \\
\text { transition program before their children started } \\
\text { school noted that over time, they formed a } \\
\text { collaboration with teacher. Mothers who are } \\
\text { unfamiliar with school culture and language found } \\
\text { regular interviews and introductory activities useful, } \\
\text { but problems with their children's success and } \\
\text { happiness continued. Educators found important to } \\
\text { participate the information sessions and workshops. }\end{array}$ & \\
\hline $\begin{array}{l}\text { Sanagavarapu, } \\
\text { 2017/ Australia }\end{array}$ & $\begin{array}{l}\text { Investigate children's } \\
\text { capacity to resist allergic } \\
\text { food cravings and ask for } \\
\text { help, as well as their } \\
\text { feelings of starting the } \\
\text { school }\end{array}$ & $\begin{array}{l}6 \text { school-age } \\
\text { children with } \\
\text { food allergies }\end{array}$ & Food allergy & Qualitative & $\begin{array}{l}\text { Interview } \\
\text { Photo Elicitation } \\
\text { Interviews (PEI) }\end{array}$ & $\begin{array}{l}\text { All of the children involved in this study have an } \\
\text { awareness of what they can and cannot eat safely, } \\
\text { but it has not been definitively determined whether } \\
\text { they recognize foods that are likely to be allergenic } \\
\text { for them. Most children stated that when they were } \\
\text { offered an allergenic food, they are refusing and } \\
\text { telling them "no". All the children indicated that } \\
\text { they would first seek help from their teachers when } \\
\text { there was an allergic reaction. }\end{array}$ & - \\
\hline
\end{tabular}


Gamze KAPLAN, Sima MART \& İbrahim Halil DİKEN

\begin{tabular}{|c|c|c|c|c|c|c|c|}
\hline $\begin{array}{l}\text { Yıldırım } \\
\text { Haccibrahimoğlu } \\
\text { \& Kargın, 2017/ } \\
\text { Turkey }\end{array}$ & $\begin{array}{l}\text { Determine the difficulties } \\
\text { experienced by students } \\
\text { with special needs during } \\
\text { the transition from } \\
\text { preschool to primary } \\
\text { education based on } \\
\text { teacher opinions }\end{array}$ & $\begin{array}{l}209 \text { primary } \\
\text { school } \\
\text { teachers } \\
43 \text { primary } \\
\text { school } \\
\text { teachers } \\
\text { working with } \\
\text { first grade }\end{array}$ & $\begin{array}{l}\text { Special educational } \\
\text { needs }\end{array}$ & $\begin{array}{l}\text { Mixed method/ } \\
\text { Explanatory } \\
\text { mixed design }\end{array}$ & $\begin{array}{l}\text { Survey } \\
\text { Focus group interview } \\
\text { Determining the } \\
\text { Difficulties in } \\
\text { Transitioning to Primary } \\
\text { School (DDTPS) } \\
\text { Questions of Focus group } \\
\text { interview }\end{array}$ & $\begin{array}{l}\text { At the first stage of the study, the subjects as having } \\
\text { the most problems in transition were: Lack of } \\
\text { appropriate materials, negative attitude of the } \\
\text { classroom teacher, crowded classrooms, lack of } \\
\text { support for the teacher and inability of the student } \\
\text { to perform their daily life skills independently. The } \\
\text { results show that the teacher's gender, level of } \\
\text { education, or special educational knowledge did } \\
\text { not make a significant difference in responses. }\end{array}$ & $\begin{array}{l}\text { Inter-rater } \\
\text { reliability, } \\
\text { Participant } \\
\text { confirmation }\end{array}$ \\
\hline $\begin{array}{l}\text { Sanagavarapu et } \\
\text { al., 2016/ Australia }\end{array}$ & $\begin{array}{l}\text { Discuss mothers' } \\
\text { concerns and feelings } \\
\text { about their child's } \\
\text { transition to school }\end{array}$ & 10 mothers & Food allergy & Qualitative & $\begin{array}{l}\text { Interview } \\
\text { Photo Elicitation } \\
\text { Interviews (PEI) }\end{array}$ & $\begin{array}{l}\text { Most mothers learned about the school's food } \\
\text { allergy management after their children started } \\
\text { school. Almost all mothers expressed concern about } \\
\text { safe playgrounds and the supervision of risk } \\
\text { elements. However, mothers have stated that they } \\
\text { are perceived by school staff as being overly } \\
\text { protective, that schools are more at risk than pre- } \\
\text { school education environments, and that } \\
\text { transferring responsibility to school staff is a } \\
\text { concern. }\end{array}$ & $\begin{array}{l}\text { Inter-rater } \\
\text { reliability }\end{array}$ \\
\hline $\begin{array}{l}\text { Carmody et al., } \\
\text { 2015/ USA }\end{array}$ & $\begin{array}{l}\text { Examine the impact of } \\
\text { child, parent, and family } \\
\text { relationship factors } \\
\text { assessed at kindergarten } \\
\text { age on children's } \\
\text { emotions/behavior, self- } \\
\text { regulation, and social } \\
\text { outcomes in primary } \\
\text { school first grade }\end{array}$ & $\begin{array}{l}92 \text { children } \\
\text { who were } \\
\text { physically } \\
\text { abused and } \\
\text { their primary } \\
\text { caregivers }\end{array}$ & Physical abuse & $\begin{array}{l}\text { Quantitative + } \\
\text { Longitudinal } \\
\text { study }\end{array}$ & $\begin{array}{l}\text { Scales and Observation } \\
\text { Kaufman Brief } \\
\text { Intelligence Test (KBIT), } \\
\text { Brief Symptom Index } \\
\text { (BSI), } \\
\text { Preschool Parenting } \\
\text { Measure (PPM), } \\
\text { MacArthur Story Stem } \\
\text { Battery, } \\
\text { Emotional/Behavioral } \\
\text { Problems the Child } \\
\text { Behavior Checklist- } \\
\text { Teacher Report Form } \\
\text { (TRF), } \\
\text { The Behavior Rating } \\
\text { Inventory of Executive } \\
\text { Functioning (BRIEF) }\end{array}$ & $\begin{array}{l}\text { Factors of low IQ score, parental mental health, and } \\
\text { family conflict in kindergarten age were found to } \\
\text { predict internal problem behaviors that occur in } \\
\text { first grade. An association was found between } \\
\text { maternal acceptance and internal problem } \\
\text { behaviors. A low IQ score and a preschool family } \\
\text { Factor were found to predict external problem } \\
\text { behaviors. Due to the deterioration of the emotional } \\
\text { and cognitive functions of children subjected to } \\
\text { abuse in kindergarten, it is argued that this } \\
\text { condition may hinder the development of stress and } \\
\text { emotion management skills during the transition to } \\
\text { first grade, so children subjected to physical abuse } \\
\text { need individualized interventions. }\end{array}$ & $\begin{array}{l}\text { Inter-rater } \\
\text { reliability } \\
\text { (for one scale) }\end{array}$ \\
\hline
\end{tabular}


Transition to school process of children with disadvantages...

\begin{tabular}{|c|c|c|c|c|c|c|c|}
\hline $\begin{array}{l}\text { Fontil \& Petrakos, } \\
\text { 2015/ } \\
\text { Canada }\end{array}$ & $\begin{array}{l}\text { Understand the } \\
\text { experiences of children of } \\
\text { Canadian and immigrant } \\
\text { families regarding the } \\
\text { transition to elementary } \\
\text { school }\end{array}$ & $\begin{array}{l}10 \text { children } \\
\text { with autism, } \\
\text { including } 5 \\
\text { Canadians } \\
\text { and } 5 \\
\text { immigrants, } \\
\text { and their } \\
\text { families }\end{array}$ & $\begin{array}{l}\text { Autism, } \\
\text { Cultural/ ethnic } \\
\text { diversity }\end{array}$ & $\begin{array}{l}\text { Qualitative/ } \\
\text { Grounded } \\
\text { Theory }\end{array}$ & $\begin{array}{l}\text { Interview } \\
\text { The question form of } \\
\text { semi-structured } \\
\text { interview, Measure of } \\
\text { Processes of Care (MPOC- } \\
\text { 20) }\end{array}$ & $\begin{array}{l}\text { All parents emphasized the importance of school- } \\
\text { family communication, which includes empathy } \\
\text { and understanding. Most families used various } \\
\text { means of support during the transition, while some } \\
\text { said they could not find support systems. Some } \\
\text { families stated that their children's difficulties } \\
\text { during the transition to primary school were due to } \\
\text { the lack of support services in the classroom. Both } \\
\text { groups of families expressed concern about their } \\
\text { children's language and communication skills, } \\
\text { while immigrant families expressed concern that } \\
\text { their language and communication skills would } \\
\text { have a negative impact on school-family } \\
\text { cooperation. }\end{array}$ & $\begin{array}{l}\text { Inter-rater } \\
\text { reliability, } \\
\text { triangulation, } \\
\text { participant } \\
\text { confirmation, } \\
\text { detailed } \\
\text { description }\end{array}$ \\
\hline $\begin{array}{l}\text { Bell-Booth et al., } \\
\text { 2014/ Australia }\end{array}$ & $\begin{array}{l}\text { Identify key factors } \\
\text { affecting the transition } \\
\text { and attendance of } \\
\text { Australian Aboriginal } \\
\text { and Indigenous children }\end{array}$ & $\begin{array}{l}2 \text { aboriginal } \\
\text { students, } \\
\text { their families } \\
\text { and teachers }\end{array}$ & $\begin{array}{l}\text { Socio-economic } \\
\text { disadvantage } \\
\text { Cultural/ethnic } \\
\text { diversity }\end{array}$ & $\begin{array}{l}\text { Longitudinal } \\
\text { study/Case } \\
\text { study }\end{array}$ & $\begin{array}{l}\text { Interview and scales } \\
\text { Settling into School Scale } \\
\text { (SIS), } \\
\text { Strengths and Difficulties } \\
\text { Questionnaire (SDQ) }\end{array}$ & $\begin{array}{l}\text { Participants had no educational experience before } \\
\text { starting primary school. The first participant was } \\
\text { absent in the first grade } 52 \% \text { of school time. } \\
\text { Although the student's language and literacy skills } \\
\text { are close to their peers, they are very limited in } \\
\text { social skills. As the student's academic skills } \\
\text { declined in the second grade and problem } \\
\text { behaviors increased, he was referred to a special } \\
\text { education class. } \\
\text { Second participant established positive social } \\
\text { relationships with his friends in the first grade and } \\
\text { achieved similar levels with his friends in the } \\
\text { academic field. In the second year, he achieved high } \\
\text { success with his orientation to sports and loved by } \\
\text { the entire school. The main difference affecting } \\
\text { success among participants was social support, } \\
\text { school practices, family conditions, child's daily } \\
\text { experience and child characteristics. }\end{array}$ & - \\
\hline
\end{tabular}


Gamze KAPLAN, Sima MART \& İbrahim Halil DİKEN

\begin{tabular}{|c|c|c|c|c|c|c|c|}
\hline $\begin{array}{l}\text { Petriwskyj, 2013/ } \\
\text { Australia }\end{array}$ & $\begin{array}{l}\text { Identify the factors that } \\
\text { teachers considered } \\
\text { effective for inclusion } \\
\text { during the transition to } \\
\text { school, and to examine } \\
\text { the influences on their } \\
\text { practice }\end{array}$ & $\begin{array}{l}22 \text { students } \\
\text { attending } \\
\text { kindergarten } \\
\text { at three } \\
\text { different } \\
\text { schools and } \\
11 \text { preschool } \\
\text { teachers }\end{array}$ & $\begin{array}{l}\text { Special educational } \\
\text { needs } \\
\text { Cultural/Ethnic } \\
\text { diversity }\end{array}$ & Case study & $\begin{array}{l}\text { Observation and } \\
\text { interview } \\
\text { Early Childhood } \\
\text { Environment Rating Scale } \\
\text { Revised ECERS-R, } \\
\text { ECERS-E Extension }\end{array}$ & $\begin{array}{l}\text { As schools vary in terms of student characteristics, } \\
\text { it wasseen that teacher views were shaped by } \\
\text { changing expectations. Professional competence of } \\
\text { teachers, continuity of services and individual } \\
\text { transition planning are the main elements reflected } \\
\text { in the change. However, legal procedures for } \\
\text { assessment have not been flexible enough to allow } \\
\text { teachers to implement applications for their point of } \\
\text { view during the transition. }\end{array}$ & $\begin{array}{l}\text { Inter- } \\
\text { observer } \\
\text { agreement, } \\
\text { Inter-rater } \\
\text { reliability }\end{array}$ \\
\hline Ames, 2012/ Peru & $\begin{array}{l}\text { Examine cultural, } \\
\text { linguistic and identity } \\
\text { confusion at school in } \\
\text { order to understand the } \\
\text { 'failures' of Indigenous } \\
\text { children in the transition } \\
\text { to primary school }\end{array}$ & $\begin{array}{l}2 \text { students } \\
\text { entering the } \\
\text { first grade, } \\
\text { their families } \\
\text { and teachers }\end{array}$ & $\begin{array}{l}\text { Cultural/Ethnic } \\
\text { diversity }\end{array}$ & Case study & $\begin{array}{l}\text { Observation and } \\
\text { interview }\end{array}$ & $\begin{array}{l}\text { First participant he had problems with the } \\
\text { transition to primary school and communication } \\
\text { with his friends. The reason for family was the } \\
\text { differences of language spoken at school and at } \\
\text { home, while the student stated that the reason was } \\
\text { that he didn't like to write and was subjected to } \\
\text { physical punishment that teacher has confirmed. } \\
\text { The mother of the second participant found } \\
\text { unnecessary for her son to play games outside of } \\
\text { school and forced him to go there, while the student } \\
\text { stated that the first class was not as fun as he } \\
\text { expected. He sometimes ran away from school and } \\
\text { played games, and was subjected to physical } \\
\text { punishment by his teacher. }\end{array}$ & - \\
\hline $\begin{array}{l}\text { Chang et al., } 2012 \text { / } \\
\text { USA }\end{array}$ & $\begin{array}{l}\text { Examine the effects of } \\
\text { socio-economic risk and } \\
\text { negative emotional state } \\
\text { on children's social } \\
\text { competence in the } \\
\text { transition to primary } \\
\text { school }\end{array}$ & $\begin{array}{l}310 \text { students, } \\
\text { their families } \\
\text { and teachers }\end{array}$ & $\begin{array}{l}\text { Ethnic diversity } \\
\text { Socio-economic } \\
\text { disadvantage }\end{array}$ & $\begin{array}{l}\text { Longitudinal } \\
\text { study }\end{array}$ & $\begin{array}{l}\text { Interview and scales } \\
\text { Cumulative risk index, } \\
\text { Negative Emotionality } \\
\text { questionnaire, } \\
\text { Social skills ratings scale }\end{array}$ & $\begin{array}{l}\text { Increases in risk factors for young children lead to } \\
\text { less developed emotion regulation ability in } \\
\text { preschool children. A relationship was found } \\
\text { between low emotion regulation ability and the } \\
\text { social inadequacy of children. }\end{array}$ & - \\
\hline $\begin{array}{lr}\text { Schishka } & \text { et } \\
\text { 2012/., } \\
\text { Zealand }\end{array}$ & $\begin{array}{l}\text { Examine the transition of } \\
\text { young children with } \\
\text { special needs to primary } \\
\text { school and their processes } \\
\text { before and after starting } \\
\text { school }\end{array}$ & $\begin{array}{l}17 \text { students, } \\
\text { their primary } \\
\text { caregivers } \\
\text { and teachers }\end{array}$ & $\begin{array}{l}\text { Special educational } \\
\text { needs }\end{array}$ & Qualitative & Interview & $\begin{array}{l}\text { Two school preparation practices that parents found } \\
\text { useful were identified. These were(1) holding } \\
\text { transition meetings and (2) making visits to the } \\
\text { school before starting. Most parents and teachers } \\
\text { noted that immediately after the transition to } \\
\text { school, the children faced difficulties, especially in } \\
\text { academic skills, depending on the types of special } \\
\text { needs, often overcoming them by making decisions } \\
\text { together. }\end{array}$ & - \\
\hline
\end{tabular}


Transition to school process of children with disadvantages...

\begin{tabular}{|c|c|c|c|c|c|c|c|}
\hline $\begin{array}{l}\text { Walker et al., } \\
\text { 2012/ Australia }\end{array}$ & $\begin{array}{l}\text { Assessing parents and } \\
\text { teachers' perceptions of } \\
\text { inclusive education, } \\
\text { support, and the success } \\
\text { of the transition. In } \\
\text { addition, to examine the } \\
\text { relationship between } \\
\text { children's disability level } \\
\text { and adult perceptions. }\end{array}$ & $\begin{array}{l}50 \text { parents } \\
\text { and } 50 \\
\text { teachers }\end{array}$ & $\begin{array}{l}\text { Developmental } \\
\text { disabilities }\end{array}$ & $\begin{array}{l}\text { Qualitative and } \\
\text { quantitative }\end{array}$ & $\begin{array}{l}\text { Interview } \\
\text { Questionnaire }\end{array}$ & $\begin{array}{l}\text { Parents stated that they were satisfied with the } \\
\text { support they received from the Prep teacher, and } \\
\text { that the teacher was understanding about the } \\
\text { disadvantage of their children and family values. } \\
\text { They found the transition program for children } \\
\text { beneficial as it supports social and school-related } \\
\text { skills. Most teachers think that children's transition } \\
\text { program is easy and somewhat easy. They find the } \\
\text { support provided to them sufficient. }\end{array}$ & - \\
\hline $\begin{array}{l}\text { Sanagavarapu, } \\
\text { 2010/ Australia }\end{array}$ & $\begin{array}{l}\text { Carry out a } \\
\text { comprehensive study of } \\
\text { the cultural and linguistic } \\
\text { needs of Bangladeshi } \\
\text { children living in Sydney } \\
\text { related to school } \\
\text { transition from the } \\
\text { perspective of families }\end{array}$ & $\begin{array}{l}10 \text { Bengali } \\
\text { parents }\end{array}$ & $\begin{array}{l}\text { Cultural/linguistic/ } \\
\text { ethnic diversity }\end{array}$ & $\begin{array}{c}\text { Qualitative/ } \\
\text { Phenomenology }\end{array}$ & Interview & $\begin{array}{l}\text { The families listed the abilities of their children to } \\
\text { express needs independently and make friends as } \\
\text { among the important factors that facilitated the } \\
\text { transition to school. The families of children who } \\
\text { had difficulty adjusting to school during the } \\
\text { transition believed that the main reason was } \\
\text { linguistic differences. Some of the parents started } \\
\text { learning English in order to make a positive } \\
\text { transition, but during the transition, most } \\
\text { participants stated that they didn't understand the } \\
\text { information provided to them by the school. }\end{array}$ & - \\
\hline $\begin{array}{l}\text { McIntyre et al., } \\
\text { 2006/ USA }\end{array}$ & $\begin{array}{l}\text { To examine the factors } \\
\text { associated with the } \\
\text { transition to school } \\
\text { adjustment in children } \\
\text { with and without } \\
\text { intellectual disability. }\end{array}$ & $\begin{array}{l}67 \text { children, } \\
\text { their mothers } \\
\text { and teachers }\end{array}$ & $\begin{array}{l}\text { Intellectual } \\
\text { disability }\end{array}$ & Quantitative & $\begin{array}{l}\text { Vineland Adaptive } \\
\text { Behavior Scales, } \\
\text { Social Skills Rating } \\
\text { System, Teacher's Report } \\
\text { Form (TRF), } \\
\text { Child Behavior Checklist } \\
\text { (CBCL), } \\
\text { The Student-Teacher } \\
\text { Relationship Scale (STRS) }\end{array}$ & $\begin{array}{l}\text { Teachers reported more problem behaviors and less } \\
\text { positive relationship about children with } \\
\text { intellectual disability (ID) than typically (TD) } \\
\text { developing children. Also, parents, rated children } \\
\text { with ID as having significantly fewer social skills } \\
\text { than typical children. }\end{array}$ & - \\
\hline
\end{tabular}


When the participants are reviewed, it is seen that the studies were conducted with students, teachers and parents. However, one of the striking points may be that specifically boys were determined as participants in the two studies. This situation is explained in two studies as boys exhibit more behavioral problems in this age range (Carmody et al., 2015; Chang et al., 2012). Consistent with this finding Belsky and Beaver (2011) claim that boys can have more behavior problem than girls because of a combination of physiological, biological, and social differences. However, according to data that provided by Wolke et al. (2000), there is not differences in behavior problems based on gender.

Another point is that mothers constitute the majority of parents in participant groups. In this case, it is thought that the roles of men and women in the social structure may have been influential. In Sanagavarapu (2018), it was stated that the invitation was sent to all parents, but only the mothers accepted the interview and this situation could also be seen in different review studies (Vermaes et al., 2005). Finally, taking children's views into account and making their voices heard in the interviews with the photo elicitation technique (Sanagavarapu, 2017; 2018) represents a very critical point in terms of human rights, equality and self-advocacy.

When the research is reviewed in terms of disadvantages, it is seen that six of the studies dealt with cultural-linguistic-ethnic diversity, six in the context of special educational needs, three in the context of socio-economic level, three in food allergies, and one in physical abuse. In some of these studies (e.g. Fontil \& Petrakos, 2015) the intersectionality of multiple disadvantages was addressed. Migration movements and intercultural interactions in the world cause changes in the understanding of one single culture (Amelina, 2010) and reveal the need for culturally-sensitive studies (Jackson, 2009) which is considered the ethnic, cultural features, values, background, faith and at the same time their stories while designing and providing the program (Resnicow et al., 2000). Considering these developments, it is expected that the disadvantage situation in the context of culture-language-ethnic origin is at the highest level in the studies reviewed.

When the methods used are examined, it is seen that qualitative research methods were used in most of the studies $(n=10)$. In them phenomenology $(n=1)$, grounded theory $(n=1)$ and case study $(n=3)$ designs were used. In addition, three of the studies are longitudinal, one quantitative research and one uses both qualitative and quantitative methods. Longitudinal studies are thought to be very useful for the literature, considering that they provide in-depth and comprehensive information through long-term data. It is provided the alterations within the context (Caruana et al., 2015) and allows us to see the differing needs and practices in the transition.

Triangulation is a way to enrich the quality of the study and increase the trustworthiness/reliability (Noble \& Heale, 2019). One of the ways to provide triangulation in the scientific research is using a variety of data collection methods (Denzin, 2009). As regards the data collection techniques used in the study, the majority of studies $(n=10)$ used at least one of the data collection methods such as interview, observation, document analysis, and standardized measurement tools, and only the interview technique was used in five of these studies (Sanagavarapu, 2010; 2017; 2018; Sanagavarapu et al., 2016; Schischka et al., 2012). It could be mentioned that the data triangulation is quite limited in these studies, and this situation is thought to create a limitation for the quality of the research. Another important point is that the researchers' reflective journal, which is an important data source in expanding the data in qualitative and mixed method research processes (Slotnick \& Janesick, 2011), was not encountered in any of the studies. Lack of reflective journals may have caused data loss, and this situation should be taken into consideration in further studies.

Reliability is used as a framework concept and basically, it is related to credibility. In qualitative and quantitative research designs reliability/trustworthiness can be provided in different ways (Cohen et al., 2018). In the context of reliability/trustworthiness, there are reliability data in six of the studies. In one of these studies (Carmody et al., 2015), the reliability data were collected for only one of the many scales used. In only one study (Fontil \& Petrakos, 2015), was there triangulation in reliability/trustworthiness data, inter-coder reliability, data triangulation, participant confirmation and detailed explanation methods were used. Most of the studies $(n=8)$ were found in journals that publish research on early childhood, and they 
were also published in journals that include family studies, child development in society, and psychology.

Table 2. The journals in which the studies were published

\begin{tabular}{ll}
\hline \multicolumn{1}{c}{ Study } & \multicolumn{1}{c}{ Journal } \\
\hline $\begin{array}{l}\text { Petriwskyj (2013) } \\
\text { Walker et al. (2012) }\end{array}$ & Australasian Journal of Early Childhood \\
Sanagavarapu (2010) & \\
Sanagavarapu et al. (2016) & \\
Schischka et al. (2012) & \\
Ames, P. (2012) & International Journal of Educational Development \\
Bell-Booth et al. (2014) & Children \& Society \\
Carmody et al. (2015) & Journal of Child and Family Studies \\
McIntyre et al. (2006) & Journal of Intellectual Disability Research \\
Chang et al. (2012) & Social Development \\
Fontil \& Petrakos (2015) & Psychology in Schools \\
Rogers (2018) & European Early Childhood Education Research Journal \\
Sanagavarapu (2017) & Cogent Education \\
Sanagavarapu (2018) & Early Childhood Education Journal \\
Ylldırım-Haciibrahimoğlu \& Kargın (2017) & Educational Sciences: Theory \& Practice \\
\hline
\end{tabular}

The journals in which the studies are published are presented in Table 2. A remarkable point is all journals are scanned in Social Science Citation Index which is the fundamental index for social science research. Additionally, five of the studies (Petriwskyj, 2013; Sanagavarapu, 2010; Sanagavarapu et al., 2016; Scischka et al., 2012; Walkers et al., 2012) are published in the same journal. It could be related with the focus topics of the journal and the country where the journal is connected.

The findings of the studies reviewed were interpreted under four headings: (a) factors affecting the transition of children, (b) problems experienced in transition, (c) collaboration in the transition, (d) advices for the process.

\section{Factors Affecting the Transition of Children}

The transition is a difficult experience for all individuals. This period is harder to tackle for children with disadvantages (Ames, 2012). Transition is a struggle not only for the children but also for their families and teachers. However, it is not a one-way process and teachers/ school staff cannot expect the child and family to simply adapt to the school. Teachers also need to be sensitive to the diversity of children's adaptation and the diversity of contextual factors that affect the adaptation of children who are new to school (Sanagavarapu, 2010). At the same time, it is necessary to determine the support that teachers and parents need in this period and to offer them through adaptations (Walker et al., 2012).

When the factors affecting the child's adaptation and social competence development was reviewed, it is seen that primarily the characteristics of the child were determinant (Bell-Booth et al., 2014; McIntyre et al., 2006). In the study conducted by Bell-Booth et al. (2014), the transition of two indigenous children was followed for four years. The findings obtained showed that the transition of the two children proceeded differently. Although financial and structural services (e.g., clothing, transportation) support the struggle to access school, it is stated that the differences in the level of participation are due to the difficulties experienced by each child individually. In another study, it is found that adaptive behaviour, self-regulation and social skills have association with a successful transition and school adjustment (McIntyre et al., 2006). In line with the findings of other studies (Correira \& Marques-Pinto, 2016; McClelland et al., 2006; O'Kane \& Hayes, 2006; Stephen \& Cope, 2003), child characteristics and the required skills for learning and adjustment is mentioned and provide a consistency. This reveals the importance of each individual in a community at the same risk having their own characteristics and skills, and of considering individual differences while addressing cultural differences.

While it is always necessary to take into account the individual characteristics of the child, it is 
generally accepted that children with disadvantages experience problems during the transition. In the study conducted by Sanagavarapu (2010), it is observed that the most important problem in the transition period of children with cultural-linguistic diversity is the language barrier. This prevents not only children but also parents from accessing information on points such as the school curriculum, the transition to school, and cooperation with teachers. Therefore, school should be prepared for the to meet the cultural and lingusitical needs of children and their families (Correia \& Marques-Pinto, 2016). In the study conducted by Ames (2012), it was found that daily school experiences contain continuous messages that outrage children's culture, language and identity. In the interviews conducted by Fontil and Petrakos (2015) with the mothers, one of the mothers stated that their child speaks half English and half Romanian at home. They stated that the child spoke Romanian while resting, and while playing, they spoke English because they thought that their toys did not understand Romanian. This situation shows the experience of the child during the period and the impact of the situation of not being understood by their peers on their life. Thus, as well as providing basic services for transition, the transition also requires sensitivity to the language and culture of the child and family in the services provided (Ames, 2012; Fontil \& Petrakos, 2015; Sanagavarapu, 2010) and programming the educational services with an inclusive approach can help to provide more balanced experiences for children and their families (Stephen \& Cope, 2003).

\section{Problems Experienced in the Transition}

When the problems experienced in the transition are reviewed, they are categorized under the headings of family-related, teacher-related, child-related and other problems.

Cooperation between all stakeholders is the key point of the effective transitions (Dockett \& Perry, 2004). However, collaboration support level could perceive differently among the stakeholders. In the interviews with teachers, it is often mentioned that the cooperation of the families is quite limited (BellBooth et al., 2014; Yıldırım-Haciibrahimoğlu \& Kargın, 2017). In accordance with this finding, a mother stated in an interview with Rogers (2018) that "school work was carried out only at the school". However, in the same study, some mothers stated that, although they wanted to participate in the educational times of their children, they lacked of knowledge and support. Similarly, in the study by Fontil \& Petrakos (2015), families stated that they thought they were judged pretty much by the school system. This situation reveals the idea that the transition is perceived differently by parents and teachers (Rogers, 2018).

Considering the problems related to teachers, it is seen that teachers have limited knowledge of the individual educational needs of the child before and during the transition, limited time, insufficient teacher training programs in terms of special education, limited in-service training and inadequate support (Yildırım-Haciibrahimoğlu \& Kargın, 2017). Also, Organisation for Economic Co-operation and Development [OECD] (2002) has expressed the association between the educational systems and consistency of teacher training. In accordance with this view, Sanagavarapu et al. (2016) states that even if teachers receive training, they need additional support in understanding and supporting the psychosocial process experienced by the family. Another important finding is that teachers do not always know in advance that there will be a child who needs additional support in their classrooms (YildirımHaciibrahimoğlu \& Kargın, 2017). Considering the importance of cooperation between stakeholders and institutions in the transition, this lack of knowledge is considered to be a factor that disrupts the entire period and reveals the need for transition staff.

As regards factors related to the child, it is emphasized that the child needs support in social competence and social skills, communication, academic and self-care skills, as well as adaptation problems and anxiety due to separation from the parents (Yıldırım- Haciibrahimoğlu \& Kargın, 2017). When other problems were evaluated, it was stated by teachers that there were problems regarding peer acceptance during the transition period (Yıldırım-Haciibrahimoğlu \& Kargın, 2017), but child, parent, and family factors did not significantly predict peer interactions in the school environment, and long-term observations were needed to determine peer interactions (Carmody et al., 2015). Peer acceptance is one of the most crucial points in starting and pursuing participation to the school system, and also it is helping to forecast the adjustment (Ladd \& Price, 1987). There are many factors are affecting the peer acceptance of 
the child within the class and one of them is social skills (Silva et al., 2019). Children with disadvantages may have a lack of appropriate social skills for different reasons, such as insufficient experience with their peers (Frostad \& Pijl, 2006). Therefore, interventions that address all these factors holistically are needed, and it is thought that it will help reduce the inequality of opportunity created by disadvantages (SeabraSantos et al., 2021).

In addition, the negative attitudes of the parents of other children, the physical characteristics of the class and the school, the difference between the preschool and the primary school and the cooperation with private supportive education centers were emphasized (Fontil \& Petrakos, 2015; Sanagavarapu et al., 2016; Yıldırım-Haciibrahimoğlu \& Kargın, 2017).

\section{Collaboration in the Transition}

As in all other transition periods, one of the most important points in the transition to primary school is collaboration (Pianta et al., 2001; Skouteris et al., 2012). Schishka et al. (2012) mention that the most important factor determining school transitions for children with special needs is collaboration. Also, in the study conducted by Fontil and Petrakos (2015), it is argued that the school climate and open communication with cooperation are the most important aspects. Cooperation between families, schools and institutions stands out in this time (Schishka et al., 2012; Walker et al., 2012).

Considering that the transition is important for the family as well as for the child, the participation of the family in this time and its role in cooperation are of great significance. Bell-Booth et al. (2014) state that the factors affecting the maintenance of family participation are providing social support, school activities, including families in practices and positive expectations. Therefore, the role of the school in this period is not only to support the child but also to support the needs of the family (Petrakos \& Lehrer, 2011). In the opinions expressed by mothers, it was emphasized that the disadvantage of the child should be taken into account in the transition planning stage, proactive communication and cooperation should be provided, family participation in discussions about the child should be supported holistically, and school policies and processes should be strengthened with knowledge (Sanagavarapu, 2018). In relation to this, parents state that working with school staff who truly care about their children's needs is the main component of communication and cooperation (Fontil \& Petrakos, 2015). One of the families stated that they had a sincere relationship with the staff at their child's kindergarten, but that they were more distant during the primary school period. Similarly, in the study conducted by Rogers (2018), mothers mentioned that they wanted the opportunity to share their opinions and concerns with the teacher, to establish a relationship of trust and to establish regular dialogue by developing their relationships outside school hours, rather than occasional meetings. Knopf and Swick (2007) emphasized three points in family involvement due to the changing needs and approaches of parents: (a) creating accessible ways to participate, (b) identifying appropriate ways to support parent involvement, and (c) creating suitable opportunities for parent's strengths and weaknesses. In addition, regarding communication and cooperation, parents stated that they were willing to participate in their children's education but their efforts were limited by lack of knowledge and the feeling that their participation was not valued (Rogers, 2018). They felt supported when teachers shared their knowledge and expertise with them (Fontil \& Petrakos, 2015). Walker et al. (2012) emphasize the importance of the support provided by the teacher, who is responsible for the transition process, to family and children (Walker al., 2012). Therefore, in this period, the story of the child should be followed, proactive communication should be established with the parents, and the individual needs and concerns of the parents and children should be listened to and understood (Sanagavarapu et al., 2016).

In a study conducted by Petriwskyj (2013) with a different perspective, the times which were considered to be effective by the school team used by the teachers in a school were carried out under the leadership of both principals and experienced teachers. The education system used to focus on the problems experienced by the child and in-school relationships rather than the strengths of the child and family-society relations. In addition, instead of strengthening the family, only family participation should be respected and choices should be accepted. During the transition, problems were experienced between 
special education personnel and classroom teachers in the context of strategies, which were stated to be related to the professional preparation stage. Although the program used does not fully meet the needs of children, it stands out in terms of initiating policy-based support.

\section{Advices for the Process}

On examination of the research, it is clear that there is a need to support and strengthen children with disadvantages and their families and to change the school system as a whole (Ames, 2012). During the transition period, the emphasis should be on eliminating situations arising from the disadvantage of the child and establishing relationships of trust. Consistent with the literature (Kırat \& Güven, 2021; Petani \& Barišić, 2021; Peters, 2010; Sakellariou \& Sivropoulou, 2010), it is claimed that the primary requirement for this is cooperation, and in the absence of cooperation and communication, the family is prevented from participating in the transition of the child (Bell-Booth et al., 2014; Sanagavarapu, 2018). As another important point, teachers should face up to and resolve their own bias in terms of disadvantage of the child by giving an example of language, culture, identity and review the way they approach them. In so doing, they should listen to children and evaluate the effects of their practices on children (Ames, 2012). They should set an example to all children in terms of inclusivity of linguistic and cultural diveristy.

The transition, friendships and relationships with teachers will develop with the support of the teacher, and this will facilitate the child's adaptation to school (Sanagavarapu, 2010). An example of transition was presented by Schischka et al. (2012), and it was stated that the teachers' appropriate use of differentiated practices in class after starting school helped children in their transition to school. In order to provide differentiate practices (making the curriculum accesible to all) to be applied, the need to provide teacher training is emphasized in the literature (Bell-Booth et al., 2014; Sanagavarapu, 2017; Sanagavarapu et al., 2016; Yıldırım-Haciibrahimoğlu \& Kargın, 2017). Given that the transition is a collaborative action, families should also be informed about transition and social, emotional and behavioral needs of children by offering training (McIntyre et al., 2006; McTaggart \& Sanders, 2003). In addition, peers and other community members should be informed, their awareness raised, and they should be cooperative on specific issues such as food allergies (Sanagavarapu et al., 2016; Sanagavarapu, 2017; YıldırımHaciibrahimoğlu \& Kargin, 2017).

Finally, two studies reviewed revealed the importance of minimizing the behavioral problems of the child with a disadvantage by means of preschool programs or early childhood home-based programs. These programs targeting children's language, communication, non-verbal problem-solving skills, and acquisition of self-management skills from early childhood (Sanagavarapu, 2017), to support and direct the child's efforts to these areas (Yildırım-Haciibrahimoğlu \& Kargın, 2017). The need for a review of inclusion practices and the development of infrastructure in schools was emphasized (Yıldırım-Haciibrahimoğlu \& Kargin, 2017).

\section{Conclusion}

Considering the overall dimensions of the research, it is seen that the studies carried out on the school transition of different disadvantage groups that need additional support are starting to stand out in different countries. However, further research is needed in order to comprehensively address the factors affecting the transition.

In the United States, Individuals with Disabilities Education Improvement Act (IDEA, 2004) requires setting transition goals and planning for the transition of children with special needs. Similarly, for all groups with disadvantages, it is important that the planning of this period be mandatory all over the world. In this context, when the communication between the institution to be transferred and the current institution will begin, what kind of practices will be made between the institutions, and what kind of team will be formed for the student are determined. It seems that the overall focus of the existing research in this area is the parent, child and teacher. However, important terms such as transition need to be planned by a team. In academic studies importance of the team for the transition times of individuals with disadvantages could be reinforced in schools, disseminated to ensure social awareness, and reflected in policies. Although 
there are practices such as repeating educational assessment and diagnosis in transitions which are legally regulated in Turkey, given the need for measures to ensure student compliance with school and access to education, and to ensure that educational stakeholders are informed, what is known about the impact of these regulations on practice is limited (Milli Eğitim Bakanlığg [MEB], 2018).

In light of the studies reviewed above, it is clear that information about who will be involved in the transition team and their responsibilities should be given to all those involved. It is obvious that it is necessary to distinguish between the responsibilities of teachers for the transition of individuals with disadvantages to school and the responsibilities of other stakeholders (e.g., primary caregiver, therapist) in the team, and to emphasize the common denominators. In cases where this distinction is not made, imbalances in workload may occur. In addition, although cooperation has been frequently emphasized in studies, the role of the team in this cooperation seems to be denied. Therefore, studies in which the role of the team is brought to the fore are needed.

\section{Limitations and Recommendations}

No country restrictions were applied to the studies included in this study. This situation created an important limitation while presenting the legal framework in the reporting of the research. In each country, the practices affect the transition in different ways, country policies either support the student during the transition or create the need for additional support. It may be recommended to consider this limitation in future studies and to carry out studies by considering country-based policies and their implementation.

In this review study, electronic screening was applied from the Central Search and Article Linker service. Although this system provides access to many databases, the data obtained does not include important platforms such as ResearchGate and Google scholar. It may be recommended to repeat the research by including these channels in future studies. Additionally, it was included only studies after 2005 to screen in order to reach up-to-date data. Future studies may work without time constraints.

Needs in transition to school may vary according to the country and student needs. Therefore, studies involving all stakeholders (e.g., child, primary caregiver, primary school teacher, preschool teacher) who experience the same process can be designed.

Although two studies examined the application of transition strategies, no studies of the effectiveness of the transition process performed or designed by the researchers were found. The development of various methods and programs is therefore recommended for future research, along with a review of their effects and monitoring of the period in order to make comparisons between methods and programs that are found effective. In addition, future action research studies or experimental studies that comprehensively address all aspects of the transition will contribute to the field.

It is recommended to make a transition assessment to practitioners with the findings obtained, to include transition goals based on this assessment in children's plans, to prepare schools for the transition process, and to ensure inter-institutional coordination. In particular, temporary positions such as temporary transition personnel can be created. These staff can act as a bridge between service providers for students who need more support and can make necessary plans by following student progress.

A year includes transition to primary school should be planned for students who are determined to have social or academic difficulties in the preschool period depending on the individual differences of the students, and a gradual transition between the two institutions should be ensured. Otherwise, children may choose to return to preschool after a while after starting primary school (Chun, 2003).

Parents are the stakeholders who spend the most time with their children and have the most comprehensive information. With sufficient knowledge and skills, they can become the most important facilitating factor for their child's transition (Woodhead \& Moss, 2007). For this purpose, families with children in early childhood should be informed regularly in order to prepare for the transition.

Steps can be taken to reduce the difference in understanding between the formal school and 
kindergarten systems and to continue the holistic approach in primary school.

The following section contains suggestions for the policy.

There are many countries within the scope of the research and each of them has different approaches. In some countries, such as Turkey, the legal basis of the transition process is rather weak. In countries such as America and Australia, there are state-based differences which are regulated by state authority. It is recommended to review existing legal regulations and adopt a research-based way by providing funding for new research to determine the effects of these regulations in practice.

There are country-based changes like Nordic countries in the formal school understanding in the current structure (Bennett, 2013). It is suggested that the development process of this change in understanding should be accelerated in other countries as well.

\section{Declarations}

Editorial Acknowledgement: The editorial process of this article was carried out by Dr. Mehmet Toran.

Acknowledgements: Not applicable.

Authors' contributions: The first and second authors coordinated all the steps of the screening and reporting. The third author supervised the research process.

Competing interests: The authors declare that they have no competing interests.

Funding: Not applicable.

\section{References}

Ahtola, A., Silinskas, G., Poikonen, P. L., Kontoniemi, M., Niemi, P., \& Nurmi, J. E. (2011). Transition to formal schooling: Do transition practices matter for academic performance?. Early Childhood Research Quarterly, 26(3), 295-302. https://doi.org/10.1016/j.ecresq.2010.12.002

Amelina, A. (2010). Searching for an appropriate research strategy on transnational migration: The logic of multi-sited research and the advantage of the cultural interferences approach. Forum: Qualitative Social Research, 11(1), 1-21. https://doi.org/10.17169/fqs-11.1.1279

Ames, P. (2012). Language, culture and identity in the transition to primary school: Challenges to indigenous children's rights to education in Peru. International Journal of Educational Development, 32(3), 454-462. https://doi.org/10.1016/j.ijedudev.2011.11.006

Atkinson, S. J., Takriti, R. A., \& Elhoweris, H. (2021). Teachers' perceptions of successful transition to school for children with and without Downs Syndrome in the UAE and England. Education, 49(7), 860-871. https://doi.org/10.1080/03004279.2020.1809489

Babbie, E (2004). The practice of social research. Thomson/Wadsworth.

Becker, B. E., \& Luthar, S. S. (2002). Social-emotional factors affecting achievement outcomes among disadvantaged students: Closing the achievement gap. Educational psychologist, 37(4), 197-214. https://doi.org/10.1207/S15326985EP3704 1

Bell-Booth, R., Staton, S., \& Thorpe, K. (2014). Getting there, being there, staying and belonging: A case study of two indigenous Australian children's transition to school. Children \& Society, 28(1), 15-29. https://doi.org/10.1111/j.1099-0860.2012.00441.x

Belsky, J. \& Beaver, K. (2011). Cumulative-genetic plasticity, parenting adolescent self-regulation. Journal of Child Psychology and Psychiatry, 52(5), 619-626. https://doi.org/10.1111/j.1469-7610.2010.02327.x

Bennett, J. (2013). A response from the co-author of 'a strong and equal partnership". In P. Moss (Ed.), Early Childhood and Compulsory Education: Reconceptualising the relationship (pp. 52-71). Routledge.

Carmody, K. A., Haskett, M. E., Loehman, J., \& Rose, R. A. (2015). Physically abused children's adjustment at the transition to school: Child, parent, and family factors. Journal of Child and Family Studies, 24(4), 957-969. https://doi.org/10.1007/s10826-014-9906-7

Caruana, E. J., Roman, M., Hernández-Sánchez, J., \& Solli, P. (2015). Longitudinal studies. Journal of Thoracic Disease, 7(11), 537-540. https://doi.org/10.3978/j.issn.2072-1439.2015.10.63

Chang, H., Shelleby, E. C., Cheong, J., \& Shaw, D. S. (2012). Cumulative risk, negative emotionality, and emotion regulation as predictors of social competence in transition to school: A mediated moderation model. Social Development, 21(4), 780-800. https://doi.org/10.1111/j.1467-9507.2011.00648.x

Chun, W. N. (2003) A study of children's difficulties in transition to school in Hong Kong. Early Child Development and Care, 173(1), 8396. https://doi.org./10.1080/0300443022000022440

Cohen, L., Manion, L., \& Morrison, K. (2018). Research methods in education (8 (th $^{\text {Ed.). }}$. Routledge. 
Transition to school process of children with disadvantages...

Correira, K., \& Marques-Pinto, A. (2016). Adaptation in the transition to school: Perspectives of parents, preschool and primary school teachers. Educational Research, 58(3), 247-264. https://doi.org/10.1080/00131881.2016.1200255

Corsaro, W. A., \& Molinari, L. (2000). Priming events and Italian children's transition from preschool to elementary school: Representations and action. Social Psychology Quarterly, 63(1), 16-33. https://doi.org/10.2307/2695878

Dahlberg, G., \& Taguchi, H. L. (1994, September 1-3). Pre-school and School: the encounter of two different traditions and a vision of a possible setting of a fruitful and creative interaction [oral presentation]. Settings in Interaction: Research and Implications. $4^{\text {th }}$ Annual Conference of the EECERA on the Quality of Early Childhood Education, Goteburg, Sweden. https://files.eric.ed.gov/fulltext/ED394617.pdf

Denzin, N. K. (2009). The research act: A theoretical introduction to sociological methods. Routledge.

Dockett, S., \& Perry, B. (2004). What makes a successful transition to school? Views of Australian parents and teachers. International Journal of Early Years Education, 12(3), 217-230. https://doi.org/10.1080/0966976042000268690

Dockett, S., Dunlop, A.-W., Einarsdóttir, J., Garpelin, A., Graue, B., Harrison, L., Lam, M.S.M., Mackenzie, M., Margetts, g., Murray, E., Perry, B., Peters, S., Petriwskyj, A., \& Turunen, T. (2014). Transition to school: Position statement. Charles Sturt University.

Einarsdóttir, J., Perry, B., \& Dockett, S. (2008). Transition to school practices: Comparisons from Iceland and Australia. Early Years, 28(1), 47-60. https://doi.org/10.1080/09575140801924689

Fontil, L., \& Petrakos, H. H. (2015). Transition to school: The experiences of Canadian and immigrant families of children with autism spectrum disorders. Psychology in the Schools, 52(8), 773-788. https://doi.org/10.1002/pits.21859

Frostad, P., \& Pijl, S. J. (2006). Does being friendly help in making friends? The relation between the social position and social skills of pupils with special needs in mainstream education. European Journal of Special Needs Education, 22(1), 15-30. https://doi.org/10.1080/08856250601082224

Gambaro, L. Stewart, K., \& Waldfogel, J. (2014). Introduction. In L. Gambraro, K. Stewart, \& J. Waldfogel (eds.), An equal start? Providing quality early education and care for disadvantaged children. (pp.1-29). Policy Press.

Graue, E. (2006). The answer is readiness- Now what is the question?. Early Education and Development, 17(1), 43-56. https://doi.org/10.1207/s15566935eed1701 3

Helm, A. F., McCormick, S. A., Deater-Deckard, K., Smith, C. L., Calkins, S. D., \& Bell, M. A. (2019). Parenting and children's executive function stability across transition to school. Infant and Child Development, 29(1), 1-19. https://doi.org/10.1002/icd.2171

Individuals with Disabilities Education Improvement Act. Public L. No. 108-446, $46 \quad$ Stat. $1487 \quad$ (2004). https://www.govinfo.gov/content/pkg/PLAW-108publ446/pdf/PLAW-108publ446.pdf

Jackson, K. F. (2009). Building cultural competence: A systematic evaluation of the effectiveness of culturally sensitive interventions with ethnic minority youth. Children and Youth Services Review, 31(11), 1192-1198. https://doi.org/10.1016/j.childyouth.2009.08.001

Kırat, E., \& Güven, B. (2021). Examination of classroom teachers views on transition from preschool to primary school and interinstitutional cooperation (example of Canakkale province). Route Educational \& Social Science Journal, 8(2), 167-182. http://dx.doi.org/10.17121/ressjournal.2917

Knopf, H. T., \& Swick, K. J. (2007). How parents feel about their child's teacher/school: Implications for early childhood professionals. Early Childhood Education Journal, 34(4), 291-296. https://doi.org/10.1007/s10643-006-0119-6

Ladd, G. W., \& Price, J. M. (1987). Predicting children's social and school adjustment following the transition from preschool to kindergarten. Child development, 58(5), 1168-1189. https://doi.org/10.2307/1130613

LoCasale-Crouch, J., Mashburn, A. J., Downer, J. T., \& Pianta, R. C. (2008). Pre-kindergarten teachers' use of transition practices and children's adjustment to kindergarten. Early Childhood Research Quarterly, 23(1), 124-139. https://doi.org/10.1016/j.ecresq.2007.06.001

McClelland, M. M., Acock, A. C., \& Morrison, F. J. (2006). The impact of kindergarten learning-related skills on academic trajectories at the end of elementary school. Early childhood research quarterly, 21(4), 471-490. https://doi.org/10.1016/j.ecresq.2006.09.003

McIntyre, L. L., Blacher, J., \& Baker, B. L. (2006). The transition to school: Adaptation in young children with and without intellectual disability. Journal of Intellectual Disability Research, 50(5), 349-361. https://doi.org/10.1111/j.1365-2788.2006.00783.x

McTaggart, P., \& Sanders, M. R. (2003). The transition to school project: Results from the classroom. Australian e-Journal for the Advancement of Mental Health, 2(3), 144-155. https://doi.org/10.5172/jamh.2.3.144

Milli Eğitim Bakanlı̆̆ı (2018, 7th July). Offical Gazette (30471). https://www.resmigazete.gov.tr/eskiler/2018/07/20180707-8.htm

Moss, P., \& Bennett, J. (2006, 26 September). Toward a new pedagogical meeting place? Bringing early childhood into the education system. Briefing paper for a Nuffield Educational Seminar. https://childcarecanada.org/sites/default/files/Bennett\%20and\%20Moss\%20(2006)\%20Towards\%20a\%20pedagogical\%20mee ting\%20place.pdf 
Noble, H., \& Heale, R. (2019). Triangulation in research, with examples. Evidence-Based Nursing, 22(3), 67-68. http://dx.doi.org/10.1136/ebnurs-2019-103145

O'Kane, M., \& Hayes, N. (2006). The transition to school in Ireland: Views of preschool and primary school teachers. International Journal of Transitions in Childhood, 2(1), 4-17.

Organisation for Economic Co-operation and Development. (2002). Educational Policy Analysis. Organisation for Economic Cooperation and Development.

Petani, R., \& Barišić, N. (2021, July 5-6). Cooperation of parents and preschool institutions in preparing children for school [paper presentation].13th International Conference on Education and New Learning Technologies, Online conference.

Peters, S. (2010). Literature review: Transition from early childhood education to school. Report to the Ministry of Education. The University of Waikato.

Petrakos, H. H., \& Lehrer, J. S. (2011). Parents' and teachers' perceptions of transition practices in kindergarten. Exceptionality Education International, 21(2), 62-73. https://doi.org/10.5206/eei.v21i2.7676

Petriwskyj, A. (2013). Pedagogies of inclusive transition to school. Australasian Journal of Early Childhood, 38(3), 45-55. https://doi.org/10.1177\%2F183693911303800307

Petriwskyj, A., Thorpe, K., \& Tayler, C. (2005). Trends in construction of transition to school in three western regions, 19902004. International Journal of Early Years Education, 13(1). 55-69. https://doi.org/10.1080/09669760500048360

Pianta, R. C., Kraft-Sayre, M., Rimm-Kaufman, S. E., Gercke, N., \& Higgins, T. (2001). Collaboration in building partnerships between families and schools: The National Center for Early Development and Learning's Kindergarten Transition Intervention. Early Childhood Research Quarterly, 16(1), 117-132. https://doi.org/10.1016/S0885-2006(01)00089-8

Pianta, R. C., Rimm-Kaufman, S. E., \& Cox, M. J. (1999). An ecological approach to conceptualizing the transition to kindergarten. In R. C. Pianta, \& M. J. Cox (Eds.), The transition to kindergarten (pp. 317-324). Brookes Publishing.

Resnicow, K. Soler, R. Braithwaite, R. L., Ahluwalia, J. S., \& Butler, J. (2000). Cultural sensitivity in substance use prevention. Journal of Community Psychology, 28(3), 271-290. https://doi.org/10.1002/(SICI)1520-6629(200005)28:3\%3C271::AIDICOP4\%3E3.0.CO;2-I

Riddell, S. \& Weedon, E. (2016). Additional support needs policy in Scotland: challenging or reinforcing social inequalities? Discourse: Studies in the cultural politics of education, 37(4), 496-512. https://doi.org/10.1080/01596306.2015.1073012

Rogers, S. (2018). 'She thinks her toys don't understand Romanian': Family engagement with children's learning during the transition to school. European Early Childhood Education Research Journal, 26(2), 177-186. https://doi.org/10.1080/1350293X.2018.1441986

Rous, B., Myers, C. T., \& Stricklin, S. B. (2007). Strategies for supporting transitions of young children with special needs and their families. Journal of Early Intervention, 30(1), 1-18. https://doi.org/10.1177\%2F105381510703000102

Sakellariou, M., \& Sivropoulou, I. (2010). Family and kindergarten cooperation within the framework of children's transition from kindergarten to primary school. International Journal of Interdisciplinary Social Sciences, 5(4), 345-359. https://doi.org/10.18848/1833-1882/CGP/v05i04/51682

Sanagavarapu, P. (2010). Children's transition to school: Voices of Bangladeshi parents in Sydney, Australia. Australasian Journal of Early Childhood, 35(4), 21-29. https://doi.org/10.1177\%2F183693911003500404

Sanagavarapu, P. (2017). Young children's knowledge of food allergy and transition to school. Cogent Education, 4(1), 1-12. https://doi.org/10.1080/2331186X.2017.1304617

Sanagavarapu, P. (2018). Experiences and support needs of mothers of children with food allergy during the transition to school. Early Childhood Education Journal, 46, 1-12. https://doi.org/10.1007/s10643-017-0880-8

Sanagavarapu, P., Said, M., Katelaris, C., \& Wainstein, B. (2016). Transition to school anxiety for mothers of children with food allergy: Implications for educators. Australasian Journal of Early Childhood, 41(4), 115-122. https://doi.org/10.1177\%2F183693911604100414

Schischka, J., Rawlinson, C., \& Hamilton, R. (2012). Factors affecting the transition to school for young children with disabilities. Australasian Journal of Early Childhood, 37(4), 15-23. https://doi.org/10.1177\%2F183693911203700403

Seabra-Santos, M., Major, S., Patras, J., Pereira, M., Pimentel, M., Baptista, E., Cruz, F., Santos, M., Homem, T., Azevedo, A. F. \& Gaspar, M. F., (2021). Transition to primary school of children in economic disadvantage: Does a preschool teacher training program make a difference? Early Childhood Education Journal, online first articles, 1-11. https://doi.org/10.1007/s10643-021$\underline{01240-y}$

Silva, J. L., Komatsu, A. V., Zequinao, M. A., Pereira, B. O., Wang, G. Y \&, Silva, M. A. (2019). Bullying, social skills, peer acceptance, and friendship among students in school transition. Estudos de Psicologia (Campinas), 36(1), 1-10. https://doi.org/10.1590/1982$\underline{0275201936 \mathrm{e} 180060}$

Skouteris, H., Watson, B., \& Lum, J. (2012). Preschool children's transition to formal schooling: The importance of collaboration 
Transition to school process of children with disadvantages...

between teachers, parents and children. Australasian Journal of Early Childhood, 37(4), 78-85. https://doi.org/10.1177\%2F183693911203700411

Slotnick, R. C., \& Janesick, V. J. (2011). Conversations on method: Deconstructing policy through the researcher reflective journal. Qualitative Report, 16(5), 1352-1360. https://doi.org/10.46743/2160-3715/2011.1302

Stebbins, R. A. (2001). Exploratory research in the social sciences: Qualitative research methods series 48. Sage Publications.

Stephen, C., \& Cope, P. (2003). An inclusive perspective on transition to primary school. European Educational Research Journal, 2(2), 262-276. https://doi.org/10.2304/eerj.2003.2.2.5

United Nations Educational, Scientific and Cultural Organization. (2010). Educational marginalization across developed and developing countries. https://unesdoc.unesco.org/ark:/48223/pf0000186608

Vermaes, I. P. R. Janssens, J. M. A M., Bosman, A. M. T. \& Gerris, J. R. M. (2005). Parents' psychological adjustment in families of children with Spina Bifida: a meta-analysis. BMC Pediatrics, 5(32), 1-13. https://doi.org/10.1186/1471-2431-5-32

Visković, I. (2018). Transition processes from kindergarten to primary school. Croatian Journal of Education, 20(3), 51-75. https://doi.org/10.15516/cje.v20i0.3326

Walker, S., Dunbar, S., Meldrum, K., Whiteford, C., Carrington, S., Hand, K., Berthelsen, \& Nicholson, J. (2012). The transition to school of children with developmental disabilities: Views of parents and teachers. Australasian Journal of Early Childhood, 37(3), 22-29. https://doi.org/10.1177/183693911203700304

Wolke, D., Woods, S., Bloomfield, L., \& Karstadt, L. (2000). The association between direct and relational bullying and behaviour problems among primary school children. Journal of Child Psychology and Psychiatry, 41(8), 989-1002. https://doi.org/10.1111/1469-7610.00687

Woodhead,M., \& Moss,P. (2007). Early childhood and primary education: Transitions in the lives of young children. early childhood in focus 2. Open University. http://oro.open.ac.uk/16667/1/ECiF2.DAT.pdf

Yıldırım Haciibrahimoğlu, B., \& Kargın, T. (2017). Determining the difficulties children with special needs experience during the transition to primary school. Educational Sciences: Theory E Practice, 17(5), 1487-1524. https://doi.org/10.12738/estp.2017.5.0135 